\title{
Jordgammen i Trolldalen
}

Innlegget nedenfor er skrevet av distriktslegen i Hasvik, Harald J. Blaauw (1889-1977), som ville ta leseren med paa «en liten tur inn i en avkrok i et av Finnmarks lægedistrikter». Det er en rystet distriktslege som forteller om sin erfaring med et legebesøk i en avsides fjordarm. Hans beretning handler om levekår som var atskillig semrere enn dagens, og om en lege som ble forferdet over det han så. På den annen side vitner selve språket han bruker om en betydelig distanse til de fattige. Legg spesielt merke til omtalen av mannens «nisseskjegg», og analogien med «en viss person fra eventyrene». Trolldalen er ikke et så upassende navn, fremhever distriktslegen til og med. Kanskje synes han også det passer på den for ham totalt uforståelige avvisningen av tilbudet om å flytte på gamlehjem? (Tidsskr Nor Lægeforen 1932; 52: 856-7). Harald J. Blaauw ble senere fylkeslege i Sogn og Fjordane.

\section{Hvad man kan opleve å se av menneskeboliger}

\author{
Av H. J. Blaauw, Hasvik
}

Efter ca. 1 times reise inn i fjorden ser vi i en ur noget som kan tydes som en gamme. Det er virkelig vanskelig å opdage den. Jeg har reist forbi der flere ganger uten å se den. Men i dag er doktoren sikkert ventet, for ut av gammen kommer gamlingen selv for at vi kan bli opmerksomme. Da jeg er kommet mig iland og entret op uren, står jeg foran det elendigste opholdssted for mennesker jeg hittil har sett. Den vesle gamle mann med det lange nisseskjegg, de grå slitte vadmelsklær og de plirende øine har ikke så lite tilfelles med en viss person fra eventyrene, og dette bestyrkes nok ydeligere da jeg ser kona, krumbøid i høieste grad, liten og kvass i målet. Jeg røber ikke for meget når jeg også forteller at stedet kalles Trolldalen. Men det jeg vil skrive om, er denne gubbes hall. Hele gammen består av ett rum. To små vinduer kaster et yderst sparsomt lys inn. For å komme inn må man nærmest krype gjennem døråpningen, og selv høiden midt under mønet er så lav at jeg ikke kan stå helt opreist. Lengden er godt 2 meter, bredden litt under. Her bor altså de to gamle. Gulv har det engang vært, men det holder nu på å råtne op. Dette lille rum gjør også tjeneste som fjøs. [...] Senger eller annet utstyr finnes ikke og er det ikke plass til. Konen og mannen tilbringer natten sovende i halvt opreist stilling på hver sin lille høisekk. [...] Men å få dem til å flytte over til et gamlehjem - ikke tale om. «Hørt slikt vås,» sier konen med sin mest skingrende stemme. De forlanger bare en papprull til taket, for når det regner eller sner så er det så ubergendes med alt det vannet som går tvers gjennem taket. 